\title{
Molecular and Cytogenetic Characterization of Fish Cell Lines and its Application in Aquatic Research
}

\author{
Naresh Sahebrao Nagpure • Akhilesh Kr. Mishra • A. S. Ninawe • \\ Avinash Rasal · Akhilesh Dubey · Amit Kumar - M. Goswami • \\ Ravindra Kumar • J. K. Jena
}

Received: 22 January 2014/Revised: 8 August 2014/Accepted: 6 January 2015/Published online: 22 December 2015

(C) The National Academy of Sciences, India 2015

\begin{abstract}
Fish cell line has emerged as an important tool in fishery biotechnology. In recent years, various fish cell lines have been developed by different researchers across the country. National Repository on Fish cell lines, established with the aim to preserve fish cell lines for training and education to stakeholders, has started functioning at National Bureau of Fish Genetic Resources, Lucknow. This repository is supposed to characterize and preserve the fish cell lines developed across the country and serve as a national referral centre for Indian and exotic fish cell lines. Currently, the repository is maintaining 50 fish cell lines deposited by various research institutes in India, including the cell lines developed at cell culture facility of National Bureau of Fish Genetic Resources. The cell lines have been successfully cryopreserved after verifying its authenticity by sequence analysis of two mitochondrial genes, viz. $16 \mathrm{~S}$ rRNA and cytochrome c oxidase sub-unit I. Chromosomal analysis, transfection efficiency and immunocytochemistry are also being used to characterize the cell lines. The facility is serviceable for the collection, deposition and
\end{abstract}

\footnotetext{
N. S. Nagpure - A. Kr. Mishra - A. Rasal - A. Dubey ·

A. Kumar · M. Goswami · R. Kumar ( $₫)$

Division of Molecular Biology \& Biotechnology, National

Bureau of Fish Genetic Resources (Indian Council of

Agricultural Research), Canal Ring Road, P.O. Dilkusha,

Lucknow 226 002, India

e-mail: ravindra.scientist@gmail.com

N. S. Nagpure

e-mail: nagpurens@yahoo.co.in

A. Kr. Mishra

e-mail: am.mishra70@gmail.com

A. Rasal

e-mail: avinashrasal44@gmail.com

A. Dubey

e-mail: engg.akhil111@gmail.com
}

distribution of fish cell lines. This paper discusses the status as well as the methodology adopted for fish cell lines development, characterization and storage at NRFC.

Keywords Cell line repository - Cryopreservation . Fish cell line $\cdot$ Molecular characterization

Cell culture is the most important means available in life sciences to study the biological activities occurring inside cells of a living body and it refers to the in vitro growth of cells taken from tissue of multicellular organisms. The cells are bathed in a culture medium containing essential nutrients and energy sources necessary for the cells survival [1] The culture environment usually consists of a suitable glass or plastic culture vessel containing a liquid or semisolid medium that supplies nutrients to the growing cells.

Fish cell lines have increased tremendously in number (283), since the development of the first permanent fish cell

\author{
A. Kumar \\ e-mail: amitbios@gmail.com \\ M. Goswami \\ e-mail: mukugoswami@gmail.com
}

A. S. Ninawe

Department of Biotechnology, Ministry of Science and

Technology, CGO Complex, New Delhi, India

e-mail: ninawe@gmail.com; ninawe@dbt.nic.in

J. K. Jena

National Bureau of Fish Genetic Resources (Indian Council of Agricultural Research), Canal Ring Road, P.O. Dilkusha,

Lucknow 226 002, India

e-mail: jkjena2@rediffmail.com 
line in 1962 from rainbow trout [2]. Although, a large number of fish cell lines have been established from freshwater and anadromous species, only a few cell lines are established from commercial marine fishes [3]. Embryonic cell lines have also been developed from some selected fishes, such as zebrafish (Danio rerio) [4, 5], medaka (Oryzias latipes) [6], sea perch (Lateolabrax japonicas) [7] Japanese flounder (Paralichthys olivaceus) [8], turbot (Scophthalmus maximus) [9] and sea bass (Dicentrachus labrax) [10].

The efforts of Dr. Dilip Kumar in early 1980s to develop fish cell lines at CIFA, Bhubaneswar and primary cultures developed from gill tissue of mrigal (Cirrhinus mrigala) [11], kidney of stinging catfish (Heteropneustes fossilis) [12] followed by caudal fin of rohu (L. rohita) [13] had given momentum to fish cell culture work in India. 50 fish cell lines, developed by different groups in the country, have been deposited to NRFC till date (Table 1). In recent years, a few embryonic stem-like cell lines also have been established by various researchers in fisheries $[14,15]$. The crustacean cell culture has gained potential scope for development of diagnostic reagents and probes for use in shrimp, crayfish and lobster industries. Despite several attempts to develop cell culture systems from crustaceans [16-20] in the country, no established cell line has been reported from crustaceans till date. The morphology, growth mode, subculture routine, DNA profile and other details of the cell line are available at: http://mail.nbfgr.res. in/nrfc/cellline.php.

The fish cell line repositories ensure availability of fish cell lines which is requisite to address certain key issues, like diagnosis of viral diseases, development of preventive as well as therapeutic measures, cytotoxicity measurements, detecting environmental changes and genotoxic effects etc. The authentication of cell lines by such repositories further certifies many things, like original source, passage number and information regarding submission to the scientific publications etc.

Major cell line repositories, including American Type Culture Collection (ATCC), European Collections of Cell Cultures (ECACC), German Collection of Microorganisms and Cell Cultures (DSMZ), have received cell line submissions from researchers across the world and authenticated all cell line submissions. The European Collections of Cell Cultures (ECACC) currently holds over 40,000 cell lines representing 45 different species and 50 tissue types, including the cell lines from different tissues of 21 fish species. Till date, out of over 3,400 cell lines deposited at the American Type Culture Collection (ATCC), 43 cell lines are from aquatic animals with 19 being fish cell lines available globally for dissemination to the researchers. A fish cell line repository exists at Department of Biology, University of Waterloo, Canada where studies on application of fish cell lines in the toxicology and ecotoxicology of fish have been done [21].

The National Bureau of Fish Genetic Resources (NBFGR), Lucknow is the premium organization mandated for fish germplasm collection, classification, cataloguing and its conservation. The Institute has been designated as a National Repository of Fish Germplasm by ICAR, Department of Agricultural Research and Education, Ministry of Agriculture and National Biodiversity Authority (NBA), Ministry of Environment and Forests. Regrettably, the cell lines developed are not available to researchers across the country after completion of time bound projects. A lot of time and resources are spent to develop the cell lines for fresh experiments. To circumvent this, National Repository of Fish Cell Lines (NRFC) has been established at NBFGR for long-term preservation and redistribution of deposited fish cell lines to interested researchers. At NRFC, methodologies for effective longterm maintenance, preservation and characterization of fish cell lines are developed and documented so that these may be reproduced in the recipient's laboratory. Currently, NRFC is maintaining 50 fish cell lines which are available to researchers for $R \& D$ work (Table 1). Photomicrograph of the cell lines is given in Fig. 1.

The objective of the repository is to acquire the fish cell lines developed by various national research laboratories for its long term preservation and distribution of the cell lines as and when required by the research community of India. Cell line deposition and request form for depositing and requesting cell lines from the repository along with many other related information are currently being available at the NRFC website hosted at NBFGR homepage.

NRFC is involved in development and characterization of new fish cell lines. So far 13 cell lines from 11 different fish species have been contributed by NBFGR cell culture facility. The National repository developed will help in preventing different research groups across the country from developing fish cell lines from different species and organs which have already been developed. Such incidents might have occurred in the past due to lack of a national level fish cell line repository in India. The establishment of national fish cell line repository in India is, thus, a meaningful step towards $R \& D$ work to enhance aquaculture production in the country.

The cell lines developed at NRFC are being characterized for growth studies, chromosomal analysis, 16S rRNA and COI sequence analysis, immunocytochemistry, transfection studies, cryopreservation and revival efficiency. The effects of different temperatures, FBS and basic Fibroblast Growth Factor (bFGF) concentrations on cell growth are examined by seeding cells at a concentration of $1 \times 10^{5}$ cells in $25 \mathrm{~cm}^{2}$ tissue culture flasks and incubated at $18,20,24,28$ and $32{ }^{\circ} \mathrm{C}$ for 7 days. Cells from triplicate 
Table 1 Fish cell lines available at NRFC-NBFGR, Lucknow

\begin{tabular}{|c|c|c|c|c|}
\hline S. no. & Name of cell line & Fish species & Organ & NRFC code \\
\hline 1. & PCF & Puntius chelynoides & Fin & NRFC001 \\
\hline 2. & SRF & Schizothorax richardsonii & Fin & NRFC002 \\
\hline 3. & TTCF & Tor tor & Fin & NRFC003 \\
\hline 4. & $\mathrm{CCF}$ & Cyprinus carpio & Fin & NRFC004 \\
\hline 5. & WAF & Wallago attu & Fin & NRFC005 \\
\hline 6. & $\mathrm{RF}$ & Labeo rohita & Fin & NRFC006 \\
\hline 7. & $\mathrm{KCF}$ & Koi carp & Fin & NRFC007 \\
\hline 8. & $\mathrm{HBF}$ & Horabragus brachysoma & Fin & NRFC008 \\
\hline 9. & PDF & Puntius denisonii & Fin & NRFC009 \\
\hline 10. & CFFN2 & Amphiprion sebae & Dorsal fin & NRFC010 \\
\hline 11. & CFBR & Amphiprion sebae & Brain & NRFC011 \\
\hline 12. & CFSP & Amphiprion sebae & Spleen & NRFC012 \\
\hline 13. & CFCP1 & Amphiprion sebae & Caudal peduncle & NRFC013 \\
\hline 14. & SISK & Lates calcarifer & Kidney & NRFC014 \\
\hline 15. & SISS & Lates calcarifer & Spleen & NRFC015 \\
\hline 16. & SIGE & Lates calcarifer & Eye muscle & NRFC016 \\
\hline 17. & IGK & Epinephelus coioides & Kidney & NRFC017 \\
\hline 18. & SICE & Catla catla & Eye muscle & NRFC018 \\
\hline 19. & $\mathrm{SICH}$ & Catla catla & Heart & NRFC019 \\
\hline 20. & $\mathrm{CB}$ & Catla catla & Brain & NRFC020 \\
\hline 21. & ICG & Catla catla & Gill & NRFC021 \\
\hline 22. & ICF & Clarius batrachus & Fin tissue & NRFC022 \\
\hline 23. & LRG & Labeo rohita & Gill tissue & NRFC023 \\
\hline 24. & DT1CPEx & Dascyllus trimaculatus & Caudal peduncle explant & NRFC024 \\
\hline 25. & DT1F4Ex & Dascyllus trimaculatus & Fin explant & NRFC025 \\
\hline 26. & DT1CPTr & Dascyllus trimaculatus & Trypsinized caudal peduncle & NRFC026 \\
\hline 27. & $\mathrm{RC} 4 \mathrm{H} 1 \mathrm{Tr}$ & Rachycentron canadum & Trypsnized heart & NRFC027 \\
\hline 28. & CTM & Catla catla & Thymus (macrophage) & NRFC028 \\
\hline 29. & CTE & Catla catla & Thymus (epithelial) & NRFC029 \\
\hline 30. & EM2HTr & Epinephelus malabaricus & Trypsinized heart & NRFC030 \\
\hline 31. & EM2GEx & Epinephelus malabaricus & Gill & NRFC031 \\
\hline 32. & EM3GEx & Epinephelus malabaricus & Gill & NRFC032 \\
\hline 33. & EM4SPEx & Epinephelus malabaricus & Spleen & NRFC033 \\
\hline 34. & СТВ & Catla catla & Blood & NRFC034 \\
\hline 35. & $\mathrm{PC} 1 \mathrm{CpTr}$ & Pomacentrus caeruleus & Trypsinised caudal peduncle & NRFC035 \\
\hline 36. & PC1F1Ex & Pomacentrus caeruleus & Fin explant & NRFC036 \\
\hline 37. & PC1L1Tr & Pomacentrus caeruleus & Trypsinised liver & NRFC037 \\
\hline 38. & HC2SPEx & Epinephelus merra & Spleen & NRFC038 \\
\hline 39. & CFF & Pristolepis rubripinnis & Fin & NRFC039 \\
\hline 40. & IEE & Etroplus suratensis & Eye muscle & NRFC040 \\
\hline 41. & IEK & Etroplus suratensis & Kidney & NRFC041 \\
\hline 42. & IEG & Etroplus suratensis & Gill & NRFC042 \\
\hline 43. & IEB & Etroplus suratensis & Brain & NRFC043 \\
\hline 44. & $\mathrm{RE}$ & Labeo rohita & Eye muscle & NRFC044 \\
\hline 45. & CSK & Channa striatus & Kidney & NRFC045 \\
\hline 46. & CSG & Channa striatus & Gill & NRFC046 \\
\hline 47. & WAM & Wallago attu & Muscle & NRFC047 \\
\hline 48. & WAG & Wallago attu & Gill & NRFC048 \\
\hline 49. & CPG & Channa punctatus & Gill & NRFC049 \\
\hline 50. & DRM & Danio rerio & Muscle & NRFC050 \\
\hline
\end{tabular}


flasks at each temperature are trypsinized and counted using a haemocytometer for a period of 1 week. Cell growth at different FBS and bFGF concentrations are studied at optimum temperature. Immuno-typing of the fish cell lines are performed with monoclonal antibodies directed against Vimentin and Cytokeratin (C-18) at different passages.

Chromosomal analysis is done by seeding cells in $75 \mathrm{~cm}^{2}$ tissue culture flasks having L-15 medium with $20 \%$ FBS. After $24 \mathrm{~h}$ incubation, medium is replaced with $10 \mathrm{ml}$ of fresh medium containing $0.1 \mathrm{ml}$ colcemid solution $\left(1 \mu \mathrm{g} \mathrm{ml}^{-1}\right)$ (Sigma-Aldrich) for arresting the cell division at metaphase and incubated at $28{ }^{\circ} \mathrm{C}$ for $2 \mathrm{~h}$. After harvesting by centrifugation $(700 \mathrm{~g}, 5 \mathrm{~min})$, the cells are suspended in a hypotonic solution consisting of $0.5 \% \mathrm{KCl}$ for $10 \mathrm{~min}$ and fixed in methanol: acetic acid (3:1). Slides are prepared following the conventional drop-splash technique [22]. The chromosomes are counted under a microscope after staining with $5 \%$ Giemsa for $10 \mathrm{~min}$.

Template DNA for PCR assays is extracted from cultured cell lines following the method described by [23]. An average 575 bp long fragment of mitochondrial 16S rRNA gene and $655 \mathrm{bp}$ long fragment of cytochrome c oxidase subunit I (COI) genes are amplified using universal primers $[24,25]$ and sequenced. The obtained sequences of PCR fragments are compared to known sequences of the species using BLASTn for confirmation.

Transfection is an important technique to introduce nucleic acid into the target cells and observing changes occurring in its morphology. At NRFC Sub confluent monolayers (with 70-80\% confluency) of cell lines are usually transfected with pEGFP-C1 plasmid using LTX and Plus Reagents (Invitrogen) using manufacturer's protocol. The green fluorescence signals are observed after $18 \mathrm{~h}$ under fluorescent microscope (Olympus).

Cryopreservation of the fish cell lines is a vital technique that allows them to remain alive for a longer period. They can be revived as and when required if maintained suitably under liquid nitrogen. At NRFC the viability of cells following storage in liquid nitrogen $\left(\mathrm{LN}_{2}\right)$ is evaluated in freezing medium at different passages. In brief, cells growing logarithmically are harvested by trypsinization and concentrated by centrifugation. The pellet is washed with PBS and cell count is adjusted to $3 \times 10^{6}$ cells per ml of L-15 medium with $20 \%$ FBS and $10 \%$ dimethyl sulfoxide (DMSO) of cell culture grade. Aliquots of $1 \mathrm{ml}$ are dispensed into $2 \mathrm{ml}$ sterile cryo-vials (10 numbers) (Nunc) hold at $4{ }^{\circ} \mathrm{C}$ for $2 \mathrm{~h},-20^{\circ} \mathrm{C}$ for $1 \mathrm{~h}$, $-80{ }^{\circ} \mathrm{C}$ overnight and then transferred into $\mathrm{LN}_{2}$ containers at $-196{ }^{\circ} \mathrm{C}$. After 6 months of storage, the cryopreserved vials are revived to check the revival efficiency. For revival, the cryo-vials containing preserved cell lines are thawed quickly in a water bath at $28{ }^{\circ} \mathrm{C}$. Freezing medium is removed by centrifugation. The cells are suspended in L-15 medium with $20 \%$ FBS and seeded into $25 \mathrm{~cm}^{2}$ tissue culture flasks. The viability of the cells is measured by trypan blue staining and the number of cells is counted using haemocytometer. The revived viable cells are used as a normal fish cell line for cellular and molecular research in fisheries.

Fish cell lines have enormous applications in biomedical research, toxicology, gene regulation, gene expressions and gene transfer [26-28]. Fish cell lines represent an essential component of diagnostic procedures for viral and bacterial pathogens [29]. The most widely employed application of fish cell cultures is the isolation of fish viruses that are agents of epizootics of commercially important aquaculture fish species. In addition to serving solely as a means of virus isolation, fish cell cultures are very useful for studying the replication and genetics of these viruses, the effect of antiviral drugs and the production of experimental vaccines. The cultured fish cells produce a wide range of biological products of commercial interest including immune-regulators, antibodies, polypeptide growth factors, enzymes, hormones etc. They are used in the development of tissue plasminogen activator, interferon, monoclonal antibodies, tumour specific antigens and for in vitro study of gene expression, transplantation analysis and cancer biology. Cell cultures are being used to identify fish cytokines and antibacterial compounds. The main advantage of cell culture is that the cell lines allow higher control of experimental conditions and at the same time reduce the variability of in vivo responses that arise due to the responses of fish to stress and environmental influences.

Fish cell cultures are also being developed as in vitro models for determining karyotypes and other aspects of cytogenetics including chromosome polymorphism, chromosome abnormalities, speciation and evolution [30]. Cell cultures of fish and shellfish can contribute indirectly to their successful farming by providing basic insights into how their growth, reproduction and health can be understood and manipulated [31]. Cell cultures are being used to understand the hormonal regulation of fish reproductive cycles. Primary pituitary cell cultures are being used to study the regulation of gonadotropin hormone (GTH) secretion in responses to gonadotropin releasing hormone (GnRH) [32, 33]. Recently, fish has emerged as a suitable model and a promising alternative to the classical mammalian systems to study vertebrate developments, in general, and skeletogenesis, in particular. To complement in vivo developmental studies and identifying signalling pathways involved in developmental processes, the fish cell lines have been developed in particular bone-derived cells [34]. Fish stem cells have the potential for use in various biotechnological works. Among them, gene targeting, germ cell transplantation and semi-cloning by nuclear transfer 

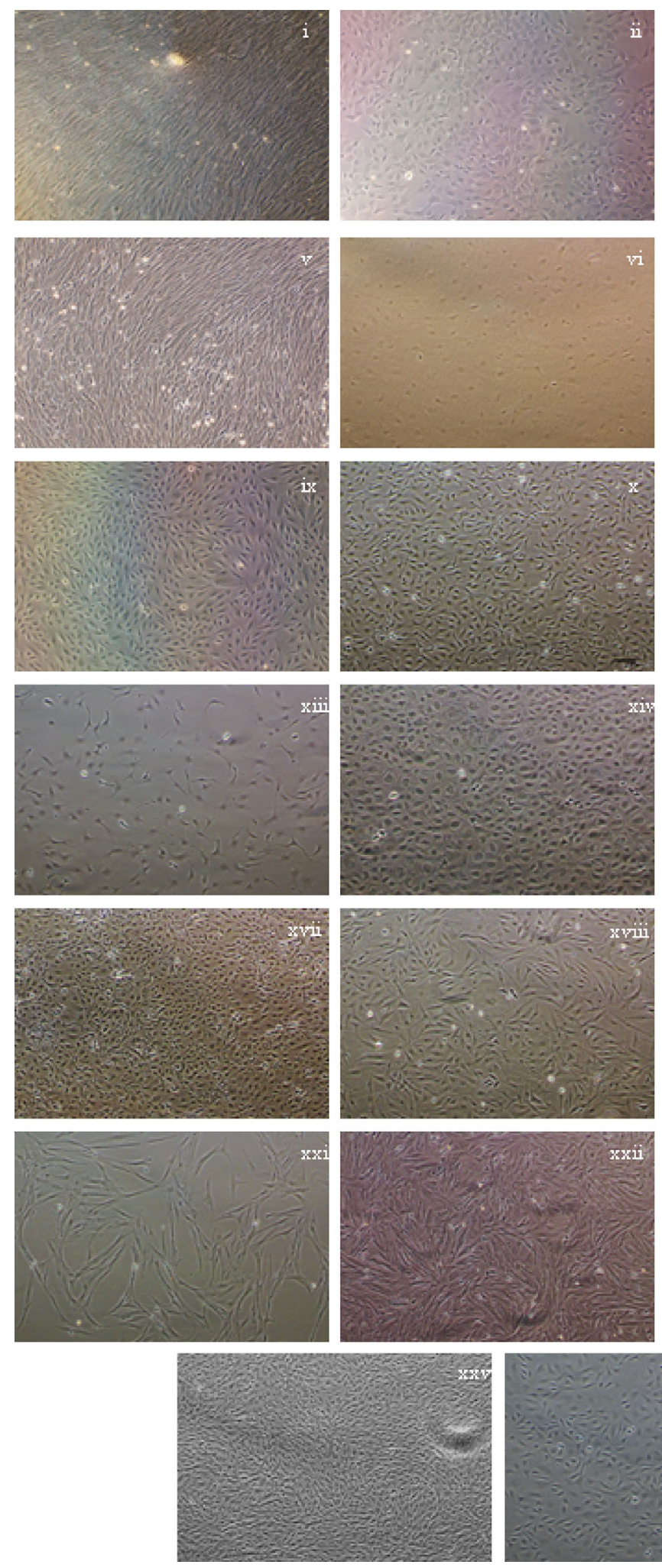

Fig. 1 Photomicrograph of few cell lines available at NRFC: i PCF ii SRF iii TTCF iv CCF v WAF vi RF vii KCF viii HBF ix PDF $\mathbf{x}$ CFFN xi CFBR xii CFSP xiii CFCP1 xiv SISK xv SISS xvi SIGE xvii IGK
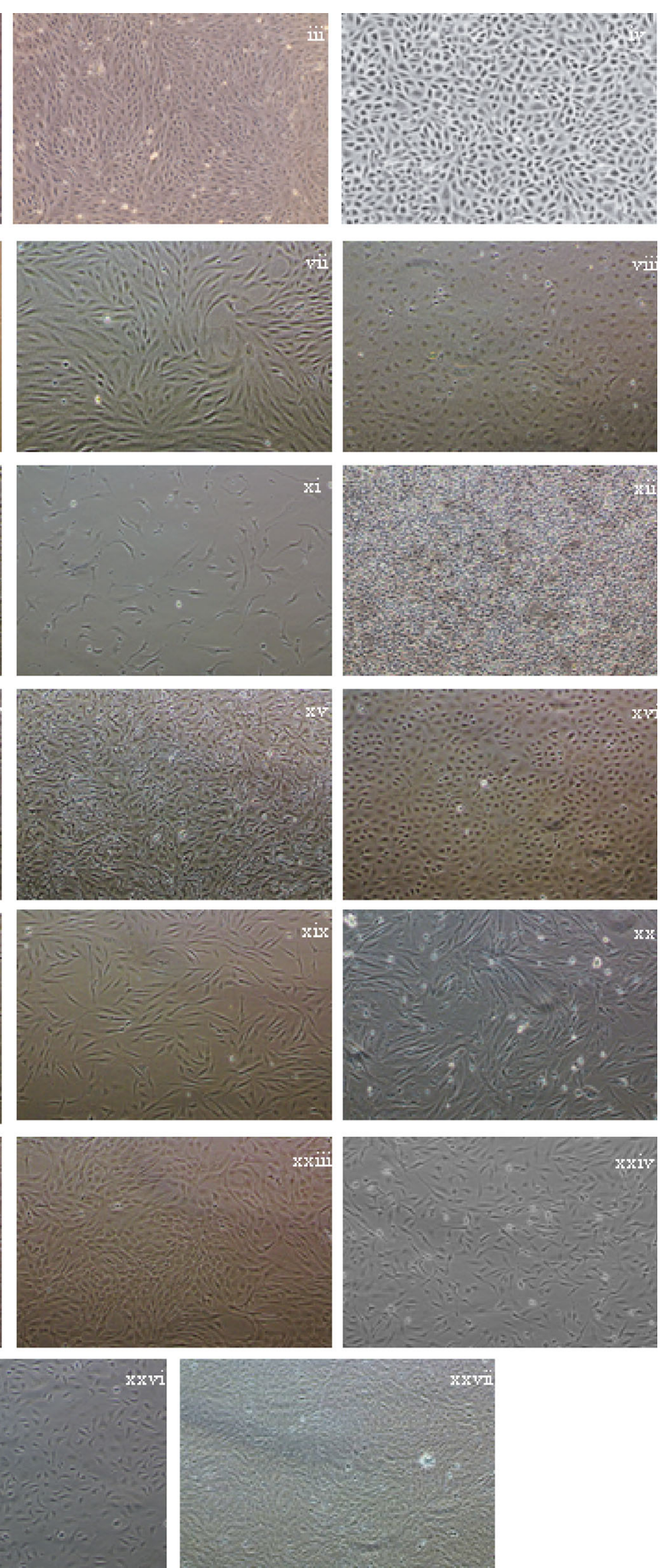

xviii SICE xix SICH $x x$ CB xxi ICF xxii ICG xxiii LRG xxiv DT1CPEx xxv DTIF4Ex xxvi DTICPTr xxvii RC4H1Tr. Lineage of the cell line have been mentioned in Table 1 
have attracted considerable interest and progress [35]. Using advanced genetic tools, the researchers from Howard Hughes Medical Institute and their collaborators have now identified key cells involved in zebrafish heart regeneration and begun to decipher the instructions to the cells used to carry out their repair work. This may have new perspective on which cells might be taught to regenerate in human hearts.

National Repository established at NBFGR, Lucknow will, thus, provide the required impetus to accelerate research in the field of fish cellular and reproductive biology. The cell lines available at the facility will be supplied to the research community upon request.

Acknowledgments The Department of Biotechnology, Government of India is thankfully acknowledged for the financial support. The authors also thank the Director, NBFGR for providing research facilities.

\section{References}

1. Martin BM (eds) (1994) Routine cell culture. Tissue culture techniques: an introduction, pp. 29-30

2. Wolf K, Quimby MC (1962) Established eurythermic line of fish cells in vitro. Science 135:1065-1066

3. Wei Y-B et al (2010) A novel heart-cell line from brown-marbled grouper Epinephelus fuscoguttatus and its susceptibility to iridovirus. J Fish Biol 76(5):1149-1158

4. Collodi P et al (1992) Culture of cells from zebrafish (Brachydanio rerio) embryo and adult tissues. Cell Biol Toxicol 8:43-61

5. Sun L et al (1995) ES-like cell cultures derived from early zebrafish embryos. Mol Mar Biol Biotech 4:193-199

6. Hong Y et al (1996) Pluripotency and differentiation of embryonic stem cell lines from the medakafish (Oryzias latipes). Mech Dev 60:33-44

7. Chen S-L et al (2003) Establishment of a pluripotent embryonic cell line from sea perch blastula embryo. Aquaculture 218:141-151

8. Chen et al (2004) Establishment of a continuous embryonic cell line from Japanese flounder Pararlichthys olivaceus for virus isolation. Dis Aquat Organ 60:241-246

9. Chen et al (2005) Development and characterization of a continuous embryonic cell line from turbot (Scophthalmus maximus). Aquaculture 249:63-68

10. Buonocore F et al (2006) Production and characterization of a continuous embryonic cell line from sea bass (Dicentrarchus labrax L.). Mar Biotechnol 8:80-85

11. Sathe PS et al (1995) Establishment and characterization of a new fish cell line, MG-3, from the gills of mrigal Cirrhinus mrigala. Indan J Exp Biol. 33:589-594

12. Singh et al (1995) Development of primary cell cultures from kidney of freshwater fish Heteropneustes fossilis. Indian J Exp Biol 33:595-599

13. Lakra WS, Bhonde RR (1996) Development of primary cell culture from the caudal fin of an Indian major carp, Labeo rohita (Ham). Asian Fish Sci 9:149-152

14. Parameswaran V, Ahmed VPI, Shukla R, Bhonde RR, Hameed ASS (2007) Development and characterization of two new cell lines from milkfish (Chanos chanos) and grouper (Epinephelus coioides) for virus isolation. Mar Biotechnol 9:281-291
15. Lakra WS et al (2010) Development and characterization of two new cell lines from common carp, Cyprinus carpio (Linn). Biol Res 43:385-392

16. Purushothaman V et al (1998) Development of in vitro primary cell culture system from penaeid shrimp, Penaeus indicus, Penaeus monodon and sand crab Emerita asiatica. Indian J Animal Sci 68(10):1097-1099

17. Kumar et al (2001) Development of a cell culture system from the ovarian tissue of African catfish (Clarias gariepinus). Aquaculture 194:51-62

18. Uma A et al (2002) Establishment of primary cell culture from hepatopancreas of Penaeus monodon for the study of whitespot syndrome virus (WSSV). Asian Fish Sci 15:365-370

19. Shashikumar A, Desai P (2008) Development of primary cell culture from Scylla serrata. Cytotechnology 56:161-169

20. Goswami et al (2010) Development of cell culture system from the giant freshwater prawn Macrobrachium rosenbergii (de Man). Mol Biol Rep 37(4):2043-2048

21. Bols NC, Dayeh VR, Lee LEJ, Schirmer K (2005) Use of fish cell lines in the toxicology and ecotoxicology of fish. In: Moon TW, Mommsen TP (eds) Biochemistry and molecular Biology of fishes-environmental toxicology, vol 6. Elsevier Science, Amsterdam, pp 43-84

22. Freshney RI (1994) Culture of animal cells: a manual of basic technique. Wiley, New York

23. Lo CF, Leu JH, Ho CH, Chen $\mathrm{CH}$, Peng SE, Chen YT, Yeh PY, Huang CJ, Wang CH, Kou GH (1996) Detection of baculovirus associated with white spot syndrome (WSSV) in penaeid shrimps using polymerase chain reaction. Dis Aquat Org 25:133-141

24. Palumbi S, Martin A, Romano S, Mcmillan WO, Stice L, Grabowski G (1991) The simple fool's guide to PCR. Version 2.0. Honolulu, HL 96822. Department of Zoology and Kewalo Marine Laboratory, University of Hawaii

25. Ward RD, Zemlak TS, Innes BH, Last PR, Hebert PDN (2005) DNA barcoding Australia's fish species. Proc R Soc London Ser B 360:1847-1857

26. Babich $\mathrm{H}$ et al (1986) In vitro cytotoxicity testing of aquatic pollutants $(\mathrm{Cd}, \mathrm{Cu}, \mathrm{Zn}, \mathrm{Ni})$ using established fish cell lines. Ecotoxicol Environ Safety 11:91-99

27. Hightower LE, Renfro JL (1988) Recent applications of fish cell culture to biomedical research. J Exp Zool 248:290-302

28. Driever W, Rangini Z (1993) Characterization of a cell line derived from zebrafish (brachydanio rerio) embryos. In Vitro Cell Dev Biol Animal 29A(9):749-754

29. Villena AJ (2003) Applications and needs of fish and shellfish cell culture for disease control in aquaculture. Rev Fish Biol Fish 13:111-140

30. Robert F (1970) Atlantic salmon (Salmo salar) chromosomes and speciation. Trans Am Fish Soc 99:105-111

31. Bols NC (1991) Biotechnology and aquaculture: the role of cell cultures. Biotech Adv 9:31-49

32. Fahraeus-van Ree GE et al (1982) The fine structure and function of isolated gonadotropic cells as revealed from pituitaries of immature rainbow trout, Salmo gairderi, by means of enzymatic dispersion technique. Cell Tissue Res 226:641-653

33. Weil C et al (1986) Use of pituitary cells in primary culture to study the regulation of gonadotropin hormone $(\mathrm{GtH})$ secretion in rainbow trout; setting up and validating the system as assessed by its responsiveness to mammalian and salmon gonadotropin releasing hormone. General Comp Endocrinol 62:202-209

34. Rafael MS et al (2010) Fish bone-derived cell lines: an alternative in vitro cell system to study bone biology. J Appl Ichthyol 26:230-234

35. Hong N, Li Z, Hong Y (2011) Fish stem cell cultures. Int J Biol Sci 7(4):392-402 